\title{
FACTORS AFFECTING THE DEVELOPMENT AND HATCHING OF EGGS AND THE SURVIVAL OF INFECTIVE LARVAE OF HAEMONCHUS CONTORTUS IN LABORATORY CONDITION
}

\author{
F. A. Ashad, Anisuzzaman, N. Begum*, A. R. Dey and M. M. H. Mondal \\ Department of Parasitology, Faculty of Veterinary Science, Bangladesh Agricultural \\ University, Mymensingh-2202, Bangladesh
}

\begin{abstract}
Haemonchus contortus Rudolphi, 1803, a blood-sucking worm living in abomasum, poses possibly the greatest threat to the livestock production. Here, we studied the effects of various environmental and nutritional factors on the development and hatching of eggs, development and survival of larvae of $H$. contortus. We incubated eggs at different temperature gradients, humidity and $\mathrm{pH}$ in phosphate buffer saline (PBS), tap water (TW) and normal saline (NS) using serum and/or liver extract at different concentrations. We obtained maximum hatching of eggs $(39.73 \%)$ at $26^{\circ} \mathrm{C}$ by day 5 . Moulting started from day 4 and maximum number of $\mathrm{L}_{2}(23.11 \%)$ developed at day 5 at $26^{\circ} \mathrm{C}$ and the highest number of $\mathrm{L}_{3}(26.81 \%)$ were detected at day 7 at $26^{\circ} \mathrm{C}$. No developments of eggs were observed, and hatching did not occur at $\mathrm{pH} 2$. Better hatching of eggs $(43.84 \%)$ were recorded in the relative humidity (RH) of $\geq 80-90 \%$. Light had no significant effects on the development and hatching of eggs of $H$. contortus. Maximum eggs hatched in PBS containing 15\% serum and 10\% liver extract. Besides, in this medium survival rate of larvae was the highest $(39.51 \%)$. The present study suggests that PBS containing 15\% serum and 10\% liver-extract may be used as a suitable medium for the incubation of eggs of $H$. contortus.
\end{abstract}

Key Words: Helminth, Haemonchus contortus, Egg, Larvae, Culture media

\section{INTRODUCTION}

Agro-ecological and geo-climatic conditions of Bangladesh are highly conducive to the growth and multiplication of a large number of parasitic species. Gastrointestinal parasitism is one of the most important disease complexes of sheep and goats impacting markedly on the livestock health and production. Haemonchus contortus Rudolphi 1803, a blood-sucking worm of the abomasum, poses possibly the greatest threat. The percentage of infection with different species of Haemonchus ranged from 50-85\% (Qadir, 1967). H. contortus is the most pathogenic of all nematodes recorded in Bangladesh. The preliminary factors that affect the development and survival of eggs and larvae are temperature and moisture although different parasites vary in their ability to survive in extremes of temperature and humidity. Laboratory informations about the effects of temperature, $\mathrm{pH}$, humidity, light and nutrients on the hatching of eggs and survival of $H$. contortus are more 
essential to study the biology and ecology of a parasite. By considering these points the present research work has been designed to investigate the effects of various environmental and nutritional factors on the development and hatching of eggs, and survival of larvae of $H$. contortus.

\section{Materials and Methods}

\section{Collection of Abomasii}

We collected abomasii from slaughter houses in Mymensingh district. During collection, each and every abomasum was ligated at both cardiac and pyloric ends and carefully separated from mesenteric and other visceral attachment and brought to the laboratory of Parasitology, Bangladesh Agricultural University, Mymensingh taking in plastic bags.

\section{Collection of parasites}

Parasites were collected from abomasii following the standard procedure as described by Rahman (1969). Parasites were identified and sexes were differentiated by examining the morphological characteristics following the keys and description given by Soulsby (1965).

\section{Recovery of eggs}

Eggs were recovered directly from the gravid $H$. contortus. For this, female parasites were crushed using sterile mortar and pastle containing necessary amounts of PBS. Debris was picked up with sterile needles, and the contents were sieved. The suspension was gently stirred to make uniform solution and eggs were counted by modified McMaster technique (Thienpont et al., 1979).

\section{Study of the effects of different media}

To find out the suitable base of the culture media, we incubated pre-counted eggs in phosphate buffer saline (PBS), normal saline (NS) and tap water (TW) at $26^{\circ} \mathrm{C}$ and $\mathrm{pH} 6.5$ in $80-96 \%$ Relative Humidity.

\section{Study of the effects of temperature}

To study the effects of temperature, eggs were incubated at various temperature gradients $\left(4-37^{\circ} \mathrm{C}\right)$. Identification of different stages of $H$. contortus larvae was made on the basis of morphological features described by Anon (1977), Soulsby (1982) and Rahman et al. (1996). Different stages of larvae were detected and percentage was counted.

\section{Study of the effects of $\mathrm{pH}$}

To study the effects of $\mathrm{pH}$, we incubated eggs over a $\mathrm{pH}$ range of 2.0-11.5 using the following buffers, $\mathrm{HCl} / \mathrm{KCl}$ for $\mathrm{pH} 2$, sodium citrate for $\mathrm{pH} 3-7$, Tris- $\mathrm{HCl}$ for $\mathrm{pH}$ 7.5-9 and sodium carbonate-bicarbonate for $\mathrm{pH} 10-11.5$. Observations were made with a dissecting microscope at every 24 hours for 7 days. 


\section{Study of the effects of humidity}

To determine the effects of relative humidity on the hatching of eggs, and survival of infective larvae, eggs were suspended in PBS and incubated at $70 \%-\leq 80 \%$ and $\geq 80 \%$ $90 \% \mathrm{RH}$ at constant $26^{\circ} \mathrm{C}$ temperature. Developmental stages were observed by dissecting microscope at every 24 for 7 days.

\section{Study of the effects of light}

To study the effects of light, eggs containing culture media was covered with black cloth to make dark condition having facilities for air exchange and incubated at room temperature. As a control, eggs were incubated in the same media in room temperature exposing to normal light, and observed in similar manner up to 8 days.

\section{Study of the effects of different nutrients}

Serum (5, 10 and 15\%) and liver extract (5, 10 and 15\%) were used to study the effects of nutrients. Combination of serum and liver extract were also tested in similar condition.

\section{Statistical analysis}

Student t-test was used to determine the statistical significance with the relevant control.

\section{RESULTS AND DISCUSSION}

\section{Maximum eggs hatched in PBS}

Of the three culture media used, maximum eggs hatched in PBS (35.1\%) followed by TW $(24.7 \%)$ and NS (13.1\%) at day 5. We found that $22.6 \%$ infective larvae survived in PBS whereas in TW and NS, $7.9 \%$ and $3.5 \%$ larvae survived, respectively at day $8 . \mathrm{L}_{3}$ developed within 8-10 days (Tables 1 and Fig. 1). Mizelle and Berberian (1953) reported that $\mathrm{L}_{3}$ of $H$. contortus developed within 6.5 days in the laboratory in faeces detection. Veglia (1916) observed that $\mathrm{L}_{1}$ hatched from eggs within 14-17 hours. The variation in development and hatching of eggs may be due to the media and other condition applied.

Table 1. Effects of media on the hatching of eggs and the survival of larvae of $H$. contortus

\begin{tabular}{|c|c|c|c|c|c|c|c|c|c|c|c|}
\hline \multirow[t]{3}{*}{ Media } & \multicolumn{11}{|c|}{ Observations (\%) } \\
\hline & \multirow[t]{2}{*}{$\mathrm{D}_{1}$} & \multirow[t]{2}{*}{$\mathrm{D}_{2}$} & \multirow[t]{2}{*}{$\mathrm{D}_{3}$} & \multirow[t]{2}{*}{$\mathrm{D}_{4}$} & \multirow[t]{2}{*}{$\mathrm{D}_{5}$} & \multicolumn{2}{|c|}{$\mathrm{D}_{6}$} & \multicolumn{2}{|c|}{$\mathrm{D}_{7}$} & \multicolumn{2}{|c|}{$\mathrm{D}_{8}$} \\
\hline & & & & & & ${ }^{*} \mathrm{D}$ & ${ }^{*} \mathrm{~L}$ & $\mathrm{D}$ & $\mathrm{L}$ & $\mathrm{D}$ & $\mathrm{L}$ \\
\hline NS & - & - & - & 10.1 & $13.1^{\mathrm{a}}$ & 8.1 & 5 & 8.5 & 4.6 & 9.6 & $3.4^{\mathrm{a}}$ \\
\hline PBS & - & - & 30.0 & 32.5 & $35.1^{b}$ & 3.2 & 31.9 & 7.8 & 27.3 & 2.7 & $22.6^{b}$ \\
\hline TW & - & - & 20.5 & 22.4 & $24.7 \mathrm{ab}$ & 4.3 & 20.4 & 9.8 & 14.9 & 16.8 & $7.9 \mathrm{a}$ \\
\hline
\end{tabular}

Values in the same column having different superscript are statistically significant $(\mathrm{P}<0.05)$. ${ }^{*} \mathrm{D}=$ dead,${ }^{*} \mathrm{~L}=$ live 

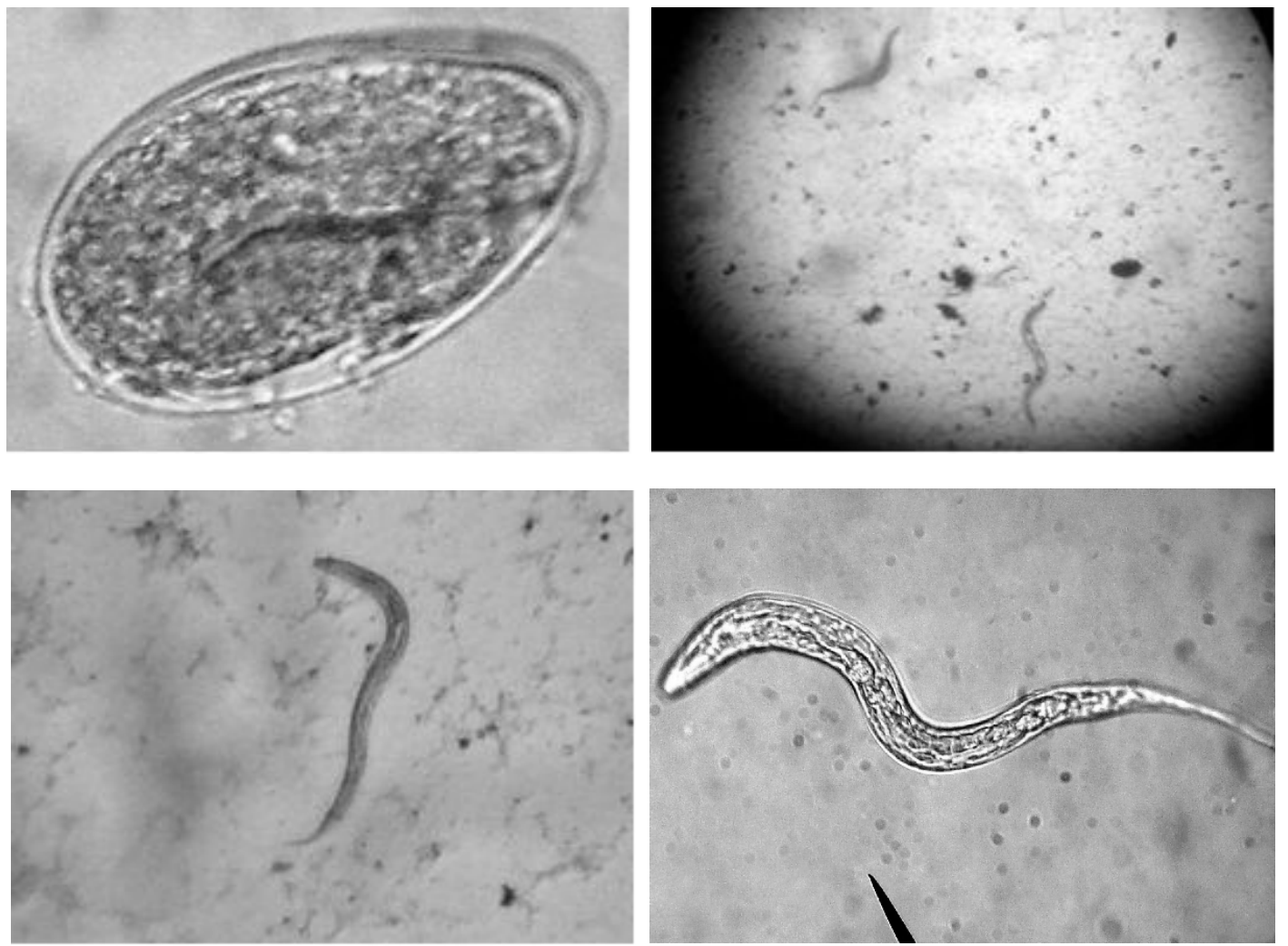

Fig. 1. Eggs and different larval stages of $H$. contortus. We incubated eggs in phosphate buffer saline (PBS) using $15 \%$ serum and $10 \%$ liver extract at $\mathrm{pH} 6.5$ and $26^{\circ} \mathrm{C}$ in $80-96 \%$ relative humidity. (a) a developing egg of $H$. contortus, (b) $\mathrm{L}_{1}$, (c) $\mathrm{L}_{2}$ and (d) $\mathrm{L}_{3}$ of the parasite

\section{Temperature $26^{\circ} \mathrm{C}$ is optimum for the hatching of eggs of $\mathrm{H}$. contortus}

We observed that developmental changes in eggs of $H$. contortus were arrested at $4{ }^{\circ} \mathrm{C}$, and failed to develop even when eggs were returned at room temperature $\left(15-20^{\circ} \mathrm{C}\right)$. Detail in the Table 2. Tripathi (1980) and Miro et al. (1991) also failed to collect larvae from the culture incubated at $4^{\circ} \mathrm{C}$, and reported that the larvae did not develop when the eggs were returned to warmer conditions. The exact mechanism of inactivation of eggs at lower temperature is not known but may be due to cold injury which squeezed the germinal mass, and the eggs were devitalized. At $9^{\circ} \mathrm{C}$ hatching of eggs delayed, which conformed to the findings of Soulsby (1982) who recorded that low temperature retarded the development of eggs, and below $9^{\circ} \mathrm{C}$ very few eggs developed. At day 8, only $6.6 \%$ larvae survived. Shorb (1944) observed that survival rate of larvae decreases in cold. At $17^{\circ} \mathrm{C}$ hatching of the eggs started at day 3, and $17 \%$ eggs developed to infective stage. Conway (1964) and Narain and Chowdhury (1979) found that eggs of $H$. contortus start to hatch at day 4 at $15^{\circ} \mathrm{C}-17^{\circ} \mathrm{C}$, and also attained infective $\mathrm{L}_{3}$ stage. At $26^{\circ} \mathrm{C}$ temperature $30 \%$ eggs hatched at day 3 and maximum 39.7\% egg hatched at day 5, and some larvae $(14.0 \%)$ attained infective stage at day 5 (Table 2). Laha et al. (2000) observed that $17.24 \%, 37.55 \%$ and $24.80 \%$ eggs hatched by 24 hours, 48 hours and 72 hours, respectively at $25-30^{\circ} \mathrm{C}$. 
Table 2. Effects of temperature on the hatching of eggs, development and survival of larvae of $H$. contortus

\begin{tabular}{|c|c|c|c|c|c|c|c|c|c|c|c|c|c|c|}
\hline \multirow[t]{3}{*}{$\begin{array}{l}\text { Temp. } \\
\text { oC }\end{array}$} & \multicolumn{3}{|c|}{ Hatching of eggs (\%) } & \multicolumn{8}{|c|}{ Development of different larval stages (\%) } & \multicolumn{3}{|c|}{$\begin{array}{c}\text { Survival of larval } \\
\text { stages }(\%)\end{array}$} \\
\hline & \multirow[t]{2}{*}{$\mathrm{D}_{3}$} & \multirow[t]{2}{*}{$\mathrm{D}_{4}$} & \multirow[t]{2}{*}{$\mathrm{D}_{5}$} & \multicolumn{2}{|c|}{$\mathrm{D}_{4}$} & \multicolumn{2}{|c|}{$\mathrm{D}_{5}$} & \multicolumn{2}{|c|}{$\mathrm{D}_{6}$} & \multicolumn{2}{|c|}{$\mathrm{D}_{7}$} & \multirow[t]{2}{*}{$\mathrm{D}_{6}$} & \multirow[t]{2}{*}{$\mathrm{D}_{7}$} & \multirow[t]{2}{*}{$\mathrm{D}_{8}$} \\
\hline & & & & $\mathrm{L}_{2}$ & $\mathrm{~L}_{3}$ & $\mathrm{~L}_{2}$ & $\mathrm{~L}_{3}$ & $\mathrm{~L}_{2}$ & $\mathrm{~L}_{3}$ & $\mathrm{~L}_{2}$ & $\mathrm{~L}_{3}$ & & & \\
\hline 4 & - & - & - & - & - & - & - & - & - & - & - & - & - & - \\
\hline 9 & - & 7.0 & $10.0^{\mathrm{a}}$ & - & - & 3.2 & - & 6.1 & 3.4 & 1.9 & $6.1^{\mathrm{a}}$ & 9.6 & 8.0 & $6.6^{\mathrm{a}}$ \\
\hline 17 & 18.3 & 26.5 & $34.2^{b}$ & 13.5 & - & 21.9 & 6.7 & 10.6 & 13.1 & 2.5 & $18.5^{\mathbf{b}}$ & 23.6 & 21 & $17.0^{\mathrm{b}}$ \\
\hline 26 & 30.0 & 37.4 & $39.7 \mathrm{~b}$ & 21 & - & 23.1 & 14.0 & 13.3 & 21.0 & 6.1 & $26.8^{\mathrm{ab}}$ & 34.3 & 32.9 & 27.5 \\
\hline 37 & 12.5 & 19.3 & $20.4^{\mathrm{ab}}$ & 10 & - & 13.3 & 2.6 & 9.8 & 10.1 & 3.7 & 14.1 & 19.9 & 17.9 & $14.6^{\mathrm{b}}$ \\
\hline
\end{tabular}

Values in the same column having different superscript are statistically significant $(\mathrm{P}<0.05)$

Tripathi (1977) found that hatching of eggs of $\mathrm{H}$. contortus required 4 days at $20^{\circ} \mathrm{C}-30^{\circ} \mathrm{C}$. $\mathrm{L}_{1}$ to $\mathrm{L}_{2}$ development required 4-12 days. $\mathrm{L}_{2}$ moulted into $\mathrm{L}_{3}$ within 13.5 days. Misra and Ruprah (1973a) observed that $22-35^{\circ} \mathrm{C}$ was suitable for development and survival of preparasitic stages of $\mathrm{H}$. contortus. Interestingly, we found that at $37^{\circ} \mathrm{C}$ hatching of eggs and the percentage of infective larvae were markedly decreased. Only $20.5 \%$ eggs hatched at $37^{\circ} \mathrm{C}$ and $14.6 \% \mathrm{~L}_{3}$ survived up to day 8 . Narain and Chowdhury (1979) and Tripathi (1977) found that very few larvae attained to the infective stage. Hernandez et al. (1992) and Tembely (1998) also found that the eggs failed to develop and larval development was low at $37^{\circ} \mathrm{C}$. Possibly, the higher temperature prevents the process of embryonic development and also kills the larvae after hatching.

\section{pH 6.5 is optimum for the development and hatching of $H$. contortus eggs}

Eggs did not develop and hatch at $\mathrm{pH} 2$ and very negligible number of eggs $(4.4 \%)$ hatched at $\mathrm{pH} 3$. Best results $(39.4 \%)$ were obtained at $\mathrm{pH} 6.5$ by day 6 (Table 3). Sommerville and Murphy (1983) also observed that eggs failed to hatch at low $\mathrm{pH}$, which is possibly due to the inactivation of related enzymes. Stringfellow (1986) and Misra and Ruprah (1973a) found that maximum hatching of eggs and development of H. contortus larvae occurred at $\mathrm{pH}$ 6.5-8.5 in laboratory condition. On the other hand, hatching of the eggs were markedly reduced at $\mathrm{pH} 11.5$ (Table 3), which is possibly due to the denaturation of the egg mass in high alkaline $\mathrm{pH}$.

\section{Maximum eggs hatched at $>80$ - 90\% relative humidity (RH)}

Maximum (43.8\%) eggs hatched at $\geq 80-90 \%$ RH whereas at $70-\leq 80 \%$ RH $34.5 \%$ eggs hatched (Table 4). Rahman et al. (1996) described that $80 \%$ RH was favourable for the hatching of eggs of $H$. contortus, and the larvae reached in infective stage within 3-4 days. Levine and Todd (1975) found more than 50\% eggs developed into infective stage in $90 \%$ RH in laboratory condition. Rossanigo and Gruner (1994) recorded 54\% hatchability of eggs when the faecal moisture content is sufficient. Krecek et al. (1992) considered RH as an important microclimatic variable for $H$. contortus since number of larvae increased in 
pasture with the increase of RH. In field condition, Fernandez et al. (1994) showed the significance of seasons on the development of eggs into infective larvae, and he made the highest recovery of $\mathrm{L}_{1}$ and $\mathrm{L}_{2}$ in monsoon. In fact, rainy season is considered as a suitable season for the development and hatching of eggs of $H$. contortus (Ndamukong and Ngone 1996 and Swarnkar et al., 1997). Moisture is considered as the most important climatic condition affecting the development and survival of infective larvae.

Table 3. Effects of $\mathrm{pH}$ on the hatching of eggs of $H$. contortus

\begin{tabular}{c|c|c|c|c|c|c|c|c}
\hline \multirow{2}{*}{ Observations } & \multicolumn{8}{c}{ Effects of different $\mathrm{pH}$} \\
\cline { 2 - 8 } & 2 & 3 & 4 & 5.5 & 6.5 & 7.5 & 9.5 & 11.5 \\
\hline Day 1 & - & - & - & - & - & - & - & - \\
Day 2 & - & - & - & - & $5 \%$ & - & - & - \\
Day 3 & - & - & $8.8 \% \mathrm{~b}$ & $21.1 \% \mathrm{a}$ & $24.7 \% \mathrm{a}$ & $23.0 \% \mathrm{a}$ & $18.6 \% \mathrm{~b}$ & $2.1 \% \mathrm{ab}$ \\
Day 4 & - & $4.4 \% \mathrm{a}$ & $12.2 \% \mathrm{~b}$ & $27.5 \% \mathrm{a}$ & $30.1 \% \mathrm{a}$ & $29.4 \% \mathrm{a}$ & $20.9 \% \mathrm{~b}$ & $6.9 \% \mathrm{ab}$ \\
Day 5 & - & $7.1 \% \mathrm{a}$ & $14.5 \% \mathrm{~b}$ & $32.3 \% \mathrm{a}$ & $34.9 \% \mathrm{a}$ & $31.0 \% \mathrm{a}$ & $23.0 \% \mathrm{ab}$ & $10.2 \% \mathrm{ab}$ \\
Day 6 & - & $9.3 \% \mathrm{a}$ & $16.0 \% \mathrm{ab}$ & $35.7 \% \mathrm{a}$ & $39.4 \% \mathrm{a}$ & $37.0 \% \mathrm{a}$ & $26.2 \% \mathrm{~b}$ & - \\
Day 7 & - & $9.6 \% \mathrm{a}$ & - & - & - & - & $27.6 \% \mathrm{~b}$ & - \\
\hline
\end{tabular}

Values in the same row having different superscript are statistically significant $(\mathrm{P}<0.05)$

Table 4. Effects of humidity, dark and light on the hatching of eggs of H. contortus

\begin{tabular}{l|c|c|c|c}
\hline \multirow{2}{*}{ Observations } & \multicolumn{2}{|c|}{ Effects of different humidity (\%) } & \multicolumn{2}{c}{ Effects of light (\%) } \\
\cline { 2 - 5 } & $70-\leq 80$ & $\geq 80-90$ & Dark & Light \\
\hline Day 1 & - & - & - & - \\
Day 2 & - & - & - & 31.1 \\
Day 3 & $27.9 \mathrm{a}$ & $35.6 \mathrm{~b}$ & 29.8 & 36.4 \\
Day 4 & $31.3^{\mathrm{a}}$ & $43.0^{\mathrm{b}}$ & 35.5 & 39.9 \\
Day 5 & $34.5^{\mathrm{a}}$ & $43.8^{\mathrm{b}}$ & 38.3 & - \\
Day 6 & 36.1 & - & - & - \\
\hline
\end{tabular}

\section{Light has no effect on the hatching of eggs}

We could not detect any significant effect of light on the development and hatching of eggs of $H$. contortus. Hatching of eggs started at day 3 on both the dark and light condition. Maximum 38.3\% and 39.9\% eggs hatched at dark and light condition, respectively (Table 4). Islam and Ahmed (1987) also found that there was no significant effect of light on the hatching of eggs and survival of larvae.

\section{Nutrient is essential for the survival of larvae}

Best results were obtained in PBS containing 15\% serum and 10\% liver extract. In this media $35.3 \%$ of eggs hatched at day 2 and gradually increased up to $45.3 \%$ at day 5 . Mortality of the larvae decreased and survival increased, and 39.5\% larvae survived at day 
8. Percentage of egg hatching, survival and longevity of the larvae increased in the media that contained serum and liver extract (Table 5). This combined media ensured a balanced environment and provide protein and several vitamins. This finding conformed to that of Paul (1965) who recorded the increased survival of larvae in a uniform manner in a medium containing plentiful food sources. He also obtained fourth stage $H$. contortus within nine days after inoculation into vitamin supplemented media. Furthermore, he observed the maximum larval survival in a medium containing $0.5 \%$ liver extract together with some extract of backer's yeast. Taken together, our results suggest that PBS containing $15 \%$ serum and $10 \%$ liver-extract may be used as suitable media for the incubation of eggs of $H$. contortus. Furthermore, better results may be obtained if eggs are incubated at $26^{\circ} \mathrm{C}$ temperature, $\mathrm{pH} 6.5$ and $\geq 80-90 \% \mathrm{RH}$.

Table 5. Effects of nutrient on the hatching of eggs and the survival of larve of $H$. contortus

\begin{tabular}{|c|c|c|c|c|c|c|c|c|c|c|c|}
\hline \multirow[t]{3}{*}{ Media } & \multicolumn{11}{|c|}{ Observations (\%) } \\
\hline & \multirow[t]{2}{*}{$\mathrm{D}_{1}$} & \multirow[t]{2}{*}{$\mathrm{D}_{2}$} & \multirow[t]{2}{*}{$\mathrm{D}_{3}$} & \multirow[t]{2}{*}{$\mathrm{D}_{4}$} & \multirow[t]{2}{*}{$\mathrm{D}_{5}$} & \multicolumn{2}{|c|}{$\mathrm{D}_{6}$} & \multicolumn{2}{|c|}{$\mathrm{D}_{7}$} & \multicolumn{2}{|c|}{$\mathrm{D}_{8}$} \\
\hline & & & & & & $\mathrm{D}$ & $\mathrm{L}$ & $\mathrm{D}$ & $\mathrm{L}$ & $\mathrm{D}$ & $\mathrm{L}$ \\
\hline PBS $+5 \%$ serum & - & 22.0 & 31.2 & 37.9 & $37.9^{a}$ & 2.7 & 35.2 & 5.0 & 32.9 & 8.0 & 29.9 \\
\hline PBS $+10 \%$ serum & - & 27.6 & 35.1 & 38.4 & $39.0^{a}$ & 1.0 & 37.9 & 3.0 & 36.0 & 6.1 & 29.9 a \\
\hline PBS + $15 \%$ serum & - & 33.4 & 37.3 & 40.7 & $41.8^{b}$ & 0.5 & 41.3 & 2.5 & 38.8 & 8.6 & $33.2 \mathrm{~b}$ \\
\hline PBS + 5\% LE & - & 21.6 & 27.0 & 38.2 & $38.5^{a}$ & 1.9 & 36.6 & 4.0 & 34.5 & 8.7 & $29.8^{a}$ \\
\hline PBS + 10\% LE & - & 31.8 & 36.0 & 39.1 & $39.8^{a}$ & 0.6 & 39.2 & 3.5 & 35.7 & 5.0 & $34.8^{b}$ \\
\hline PBS + 15\% LE & - & 28.2 & 32.4 & 37.5 & $38.7 \mathrm{a}$ & 2.8 & 35.9 & 3.0 & 35.6 & 6.6 & $32.0^{b}$ \\
\hline PBS $+15 \%$ serum $+10 \%$ LE & - & 35.3 & 38.2 & 42.0 & $45.3^{b}$ & 1.5 & 43.8 & 3.9 & 41.4 & 5.8 & $39.5^{\mathrm{ab}}$ \\
\hline
\end{tabular}

Values in the same column having different superscript are statistically significant $(\mathrm{P}<0.05)$, $\mathrm{LE}=$ Liver extract, $\mathrm{D}=$ Dead; $\mathrm{L}=$ Live

\section{REFERENCES}

Anon, 1977. Manual of Veterinary Parasitology Laboraotry Techniques. Second edition. (HMSO) Her Majesty's Stationary Office. Roben dene Amersham Ltd. England, pp. 14-23.

Conway, D. P. 1964. Some effects of temperature on the development and activity of Haemonchus contortus larvae. Cornell Veterinarian. 54(3): 266-270.

Fernández, R. M., Vázquez, P. V. and Liebano, H. E. 1994. Development and recovery of Haemonchus contortus first larval stages on experimental plots in Mexico. Veterinary Parasitology. 51(3-4): 263-369.

Hernandez, E. L., Prats, V. V. and Ruiz, A. C. 1992. Determination and estimation of the infective larvae of gastro-intestinal nematodes on pasture during two periods of the year in a humid tropical climate. Tecnica Pecuaria en Mexico., 30(1): 31-36. 
Islam, K. S. and Ahmed, S. 1987. Effect of temperature, light and darkness on the hatching of eggs and development of $\mathrm{L}_{3}$ larvae of gastrointestinal helminths and migratory behaviour of larvae in grass blades. Indian Journal of Parasitology., 11(1): 45-49.

Krecek, R. C., Groeneveld, H. T. and Maritz, J. I. 1992. A preliminary study of the effect of microclimate on third-stage larvae of Haemonchus contortus and Haemonchus placei on irrigated pasture. International Journal of Parasitology. 22(6): 747-752.

Laha, R., Bhattacharya, D., Ramakrishna, C. and Sikdar, A. 2000. In vitro egg laying capacity, percent hatchability and thereby recovery of infective larvae of Haemonchus contortus of goats. Journal of Parasitology and Applied Animal Biology., 9(2): 97-100.

Levine, N. D. and Todd, K. S. 1975. Micrometeorologica factors involved in development and survival of free living stages of the sheep nematodes Haemonchus contortus and Trichostrongylus colubiriformis. International Journal of Biomet., 22(6): 747-752.

Miro, G., Meana, A. and Rajo, V. F. A. 1991. The effect of temperature on the development of Haemonchus contortus (Rudolphi, 1803). Medicina Veterinaria., 8(9): 473-475.

Misra, S. C. and Ruprah, N. S. 1973a. Effects of temperature, relative humidity and $\mathrm{pH}$ on Haemonchus contortus eggs. International Veterinary Journal., 50(2): 136-142.

Misra, S. C. and Ruprah, N. S. 1973b. Development of H. contortus eggs. International Veterinary Journal., 50(3): 231-233.

Mizelle, J. D. and Berberian, J. A. 1953. Developmental rate of the sheep stomach worm Haemonchus contortus. Processed of Indian Academic Science., 62: 320-321.

Narain, B. and Chowdhury, H. S. 1979. Effect of temperature on the free living stages of Haemonchus contortus. Indian Biology. 3: 54-56.

Ndamukong, K. J. N. and Ngone, M. M. 1996. Development and survival of Haemonchus contortus and Trichostrongylus sp. on pasture in Cameroon. Tropical Animal Health and Production., 28(3): 193-198.

Paul. H. S. 1965. In vitro Cultivation Procedures for Parasitic Helminths. Advances in Parasitology Academic Press. London, 3: pp. 159-218.

Qadir, A. N. M. A. 1976. Investigation on the incidence of gastrointestinal parasites of the goat in the East Pakistan Agricultural University Campus, Ceylon. Veterinary Journal., 15: 58-61.

Rahman, M. H. 1969. Taxonomic study of the helminth parasites encountered in the abomasums of ruminates in East Pakistan. M. Sc. Thesis. Department of Parasitology, Bangladesh Agricultural University, Mymensingh.

Rahman, M. H., Mondal, M. M. H. and Ahmed, S. 1996. Introduction to Helminth Parasites of Animals and Birds in Bangladesh. First Edition. Mr. Taehsins Mostafa, Pvt. Ltd.

Rossanigo, C. E. and Gruner, L. 1994. Relative effect of temperature and moisture on the development of strongyle eggs to infective larvae in bovine pats in Argentina. Veterinary Parasitology., 55(4): 317-325.

Shorb, D. A. 1984. Survival on grass plots of eggs and larvae of the stomach worm Haemonchus contortus. Journal Agricultural Research., 68(8): 317-324.

Sommerville, R. I. and Murphy, C. R. 1983. Reversal of order of ecdysis in Haemonchus contortus (Nematoda). Journal of Parasitology., 69(2): 368-371. 
Soulsby, E. J. L. 1982. Helminths Arthropds and Protozoa of Domesticated Animal. 7th edn, Bailliere Tindal, London.

Soulsby, E. J. L. 1965. Text book of Veterinary Clinical Parasitology. 1, Helminths, Blackwell, Oxford.

Stringfellow, F. 1986. Cultivation of Haemonchus contortus (Nematoda: Trichostrongylidae) from infective larvae to the adult male and the egg-laying female. Journal of Parasitology. 72(2): 339-345.

Swarnkar, C. P., Singh, D., Khan, F. A., Srivastava, C. P. and Bhagwan, P. S. K. 1997. Development and survival of Haemonchus contortus larvae on pasture under semi arid conditions of Rajasthan. Journal of Veterinary Parasitology., 11(1): 37-41.

Tembely, S. 1998. Development and survival of infective larvae of nematode parasites of sheep on pasture in a cool tropical environment. Veterinary Parasitology., 79(1): 81-87.

Thienpont, D., Rochette, F. and Van P. O. F. J. 1979. Diagnosing Helminthiasis Through Coprological Examination. Janseen Research Foundation, Beerse, Belgium.

Tripathi, J. C. 1977. Effect of different temperatures on infective larvae of Haemonchus contorts under laboratory conditions. Indian Journal of Animal Science., 47(11): 739-742.

Tripathi, J. C. 1980. Effect of different temperatures on the eggs of gastrointestinal nematodes of goats under controlled conditions. International Veterinary Journal., 57: 719-722.

Veglia, F. 1916. The anatomy and life history of Haemonchus contortus. The Third and Fourth Reports of the Director of Veterinary Research. Union of South Africa, pp. 349-500. 